\title{
建物一地盤連成系模型の振動台実験による杭基礎への地震作用の基本性状 FUNDAMENTAL CHARACTERISTICS ON SEISMIC EFFECT TO PILE FOUNDATION BY SHAKING TABLE TEST FOR MODEL OF BUILDING-SOIL INTERACTION SYSTEM
}

\author{
·飯 場 正 紀*, 田守 伸一郎**,'北川 良和*** \\ Masanori IIBA, Shin'ichiro TAMORI and Yoshikazu KITAGAWA
}

\begin{abstract}
In order to clarify seismic action to a pile foundation and stress of piles in a soil-structure interaction system, a shaking table test on a model of superstructure, pile foundation and soil déposit was carried out. Effects of the sway and rocking motions of foundations and vibrations of the soil deposit on the pile foundation are investigated. Especially the effect of the contact condition between an embedment of foundations and surrounding soil, that is, backfill and friction at the embedment, on the stress of piles is focused. The backfill is very effective to reduce the force to piles, and the rocking motion of embedment has much influence to the bending moment of piles.
\end{abstract}

Keywords : Frame with wall column, Model specimen, Shaking table test, Seismic action, Rocking motion of embedment, Pile bending moment 壁式ラーメン構造、模型試験体、振動台実験、地震作用、基礎回転動、杭曲げモーメント

1.はじめに

軟弱地盤における建物の耐震設計においては、建物と地盤との動 的相互作用効果が重要であり、この効果を検証するためにこれまで に地震観測や振動実験（振動台実験、起振機実験）が行われてきた。 解析的な研究も含めた動的相互作用研究の近年の動向に関しては、 井口によって要約されている 1)。建物への有効入力や建物周期特性 などの動的相互作用現象の解明には地震動観測結果に基づいた検討 が必要であることから、1970 年代から上部構造、杭基礎および表層 地盤の同時地震動観測が始められた 233)。その後、建物や地盤の加速 度のみでなく、杭のひずみや基礎根入れ部土圧の観測も追加される

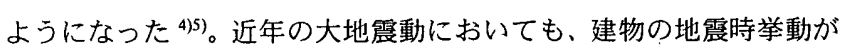
観測され、動的相互作用の観点からの現象解明がなされる ${ }^{67) と と も ~}$ に、大地震動における動的相互作用効果の建物応答への影響 ${ }^{8)}$ に関 する議論が活発になってきた。また、高層建物や免震建物のような、 特殊な建物でない一般的な中低層建物の地震動観測データが非常に 少ないことを踏まえ、一般的な建物における地震動観測が始められ ている ${ }^{910)}$ 。しかし地震動観測に基づく検討は、貴重なデータを提 供するもののケーススタディ的な検討にとどまることが多く、動的 相互作用に関する要因を総合的に分析するには長期間の観測結果の 蓄積が必要となっている。

建物の地震時挙動は、上部構造の振動特性に加えて表層地盤の振 動特性の影響を大きく受けるため、上部構造のみならず表層地盤の 動的性状も加味した現象の把握が重要となる。建物の基礎部分は、 地震動が作用する部分であるとともに、上部構造の慣性力に抵抗す
る部分でもある。特に杭基䃈に生じる応力・変形の算定においては、 上部構造の慣性力と表層地盤の振動(外力として地盤变位も含むこ とから、合わせて地震作用と呼ぶ) の影響度について検討する必要 がある。JR関連の設計基準では古くから地盤変位の影響を取り入れ た地震作用の考え方(応答変位法と呼ばれている)が示されていた ${ }^{11)}$ 地盤変位の影響 ${ }^{12) 13)}$ とともに、基礎構造の安全性に関するクライテ リアに関する研究 ${ }^{14)}$ も杭基礎の耐震設計に不可欠であり、基礎の根 入れ効果についても真剣に議論する時期となっている. ${ }^{15)}$ 。

今回、上部構造として動的相互作用効果が大きくなる比較的剛性 の高い壁式ラーメン鉄筋コンクリート構造を対象とし、上部構造一 基礎構造一地盤連成系の縮小模型を用いた振動台実験を行う機会を 得た ${ }^{16)}$ 。本論文では、上部構造の振動特性と杭基礎の入力・抵抗機 構に及ほす動的相互作用の基本性状を明らかにするために、模型試 験体の設計の考え方を示すとともに、実験結果に基づいて、基礎入 力動や上部構造の周期・減衰特性等への動的相互作用の影響を検討 した。さらに基礎根入れ部周辺の地盤条件の違いによる上部構造の ベースシア・転倒モーメントおよび地盤変位の杭曲げモーメントへ の影響度について検討を加えた。ここでは上部構造、基礎構造、地 盤ともに弾性的挙動を示す領域を検討範囲としている。

\section{2. 杭基礎への地震作用 (入カと抵抗機構)の概念}

図 1 に、上部構造一杭基礎一地盤連成系における基礎部分での入

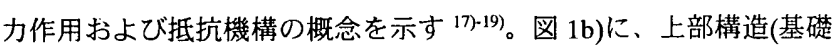
根入れ部の質量も含む)を取り除いた杭基礎一地盤系の状態を示す。

\footnotetext{
* 独立行政法人建築研究所構造研究グループ 上席研究員 - 博士 (工学)

** 信州大学工学部建設工学科 助教授. 工博

****慶應義塾大学理工学部システムデザイン工学科 教授. 工博
}

Chief Research Engineer, Structural Engineering Group, Building Research Institute, Dr. Eng.

Assoc. Prof., Architecture \& Civil Engineering, Faculty of Engineering, Shinshu University, Dr. Eng.

Prof., Department of System Design Engineering, Faculty of Science and Technology, Keio University, Dr. Eng. 


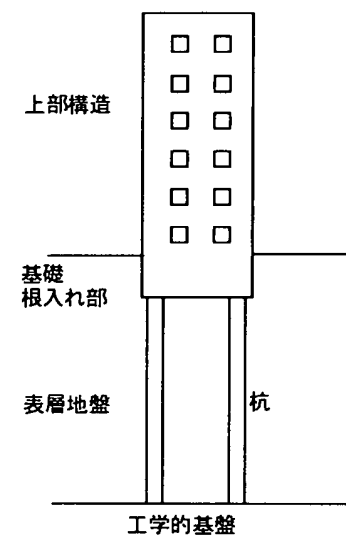

a)全体系モテル

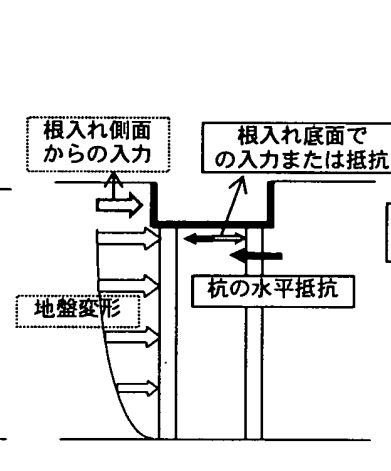

b)表層地盤が共振する場合

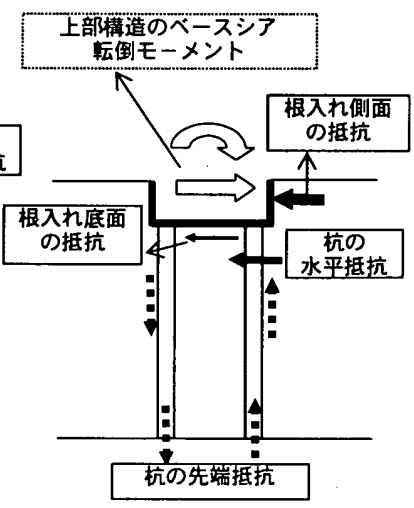

c)上部構造が共振する場合

図 1 地盤振動および上部構造(基礎根入れ部を含む)の慣性力作用時の力の釣合

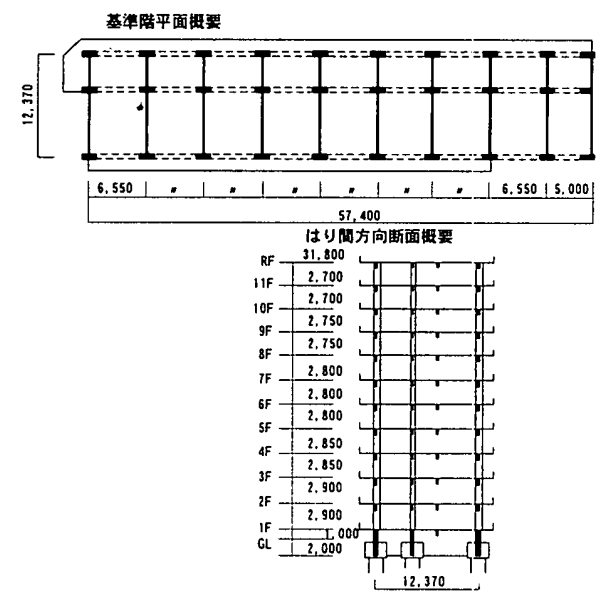

図 211 階建 HFW 建物の概要(単位 $\mathrm{mm}$ )
工学的基盤の下方から鈶直入射した地震動により表層地盤が共振す る場合を想定すると、地盤変位により強制され杭に変位が発生する。 また基礎に根入れ部分を有すると、根入れ側面に作用する土圧は根 入れ部分を押す方向に作用し、入力作用となる。一方抵抗要素は主 に杭の水平抵抗であり、根入れ部底面の摩擦力は入力または反力と して作用すると考えられる。図 1c)のように、上部構造が共振する 状態では、上部構造(基礎根入れ部も含む)からの慣性力によるべー スシアや転倒モーメントが杭基礎に作用し、根入れ部分には水平変 位(以下スウェイ変位)や回転角(以下ロッキング角)が生じる。上部構 造のベースシアに対し、根入れ部側面の土圧や底面の摩擦および杭 で抵抗し、転倒モーメントに対しては杭周面の摩擦力および杭先端 反力等、主に杭の軸方向で抵抗する。実際の地震時の挙動は、図 1 のb)と c)の状態が重ね合わされることになる。

\section{3. 模型試験体を用いた振動台実験}

\section{1 模型試験体の設計条件と実験パラメータ}

建物の原型は 8 階、11 階、14階壁式ラーメン鉄筋コンクリート構 造の建物（以下、HFW(High-rise Framed Structures with Wall Columns) 建物と呼ぶ）である。図 2 に、11階建 $\mathrm{HFW}$ 建物の基淮階平面と断 面を示す。HFW 建物の構造形式は析行方向が扁平な壁柱と同じ厚さ の梁からなる壁式ラーメンであり、梁間方向は両端に壁柱を有する 独立耐震壁構造となっている。本実験では、HFW 建物の梁間方向の 振動性状に着目し、桁行方向 2 スパン分を模型化した。

模型試験体を設計する時、相似則をどう考えるかが検討項目とな る。すべての物理定数において、実際の構造物と相似な模型を作製 することは不可能であることから、模型の設計にあたって、カと変 形の関係の相似性を満足させるためには、どの 相似比を満足させるかをあらかじめ検討してお く必要がある ${ }^{20)}$ 。

本実験で用いた相似比を表 1 に示す。相似比 の決定にあたっては、まず、長さ、加速度、密 度を設定相似比とし、他の物理量はバッキンガ

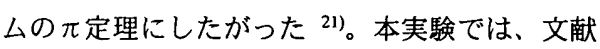
22)、23)に示された模型化の考え方を参照し、ま た同種の材料を用いることとした。重力場での 実験であることにより加速度の相似比を 1 、地

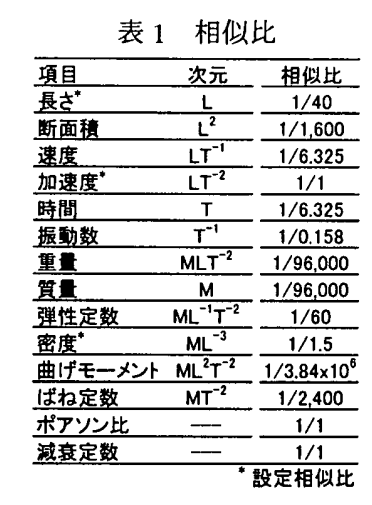

盤材料における原型地盤と模型地盤の関係から密度の相似比を $2 / 3$ 、 振動台の寸法・性能に基づく、模型試験体重量や地盤・建物模型の 大きさの関係より、長さの相似比を $1 / 40$ とした。

設定した主なパラメータは、上部構造、地盤、基礎構造、基礎根 入れ部周辺地盤状況である。実験シリーズを表 2 に示す。表中の○ 印について実験を行った。

a) 上部構造(3 種類)：上部構造のモデルとして、11 階建モ:デルの他 に、8階建、15階建モデル(14階原型建物に 1 層を追加)を:考えた。

b) 地盤(2 種類) : 建築基準法に示される第 2 種地盤(中程度) と第 3 種地盤(軟弱)に相当する単層地盤(原型地盤の深さは $24 \mathrm{~m}$ 程度、 せん断波速度はそれぞれ 200、100 $/ \mathrm{s}$ )を設定した。

c) 基礎構造形式(2 種類) : 杭基礎が対象であるが、杭を刵りり除いた 基礎(以下、直接基礎と呼ぶ)を追加し、杭の有無による動的相互 作用効果を比較する。地下階がない場合および地下 1 皆(地下 1 階は直接基礎のみ)の基礎根入れ部の深さは 11 階建建:物高さの 約 $8 \%$ 、約 $16 \%$ を設定した。

$$
\text { 表 } 2 \text { 実験シリーズ }
$$

\begin{tabular}{|c|c|c|c|c|c|c|c|c|}
\hline \multirow{2}{*}{$\begin{array}{c}\text { 基磽形式 } \\
\text { 条件 } \\
\end{array}$} & \multirow{2}{*}{$\begin{array}{c}\text { 地盤条 } \\
\text { 件 }\end{array}$} & \multirow{2}{*}{$\begin{array}{l}\text { 基礎根入れ } \\
\text { 深さ条件 }\end{array}$} & \multirow{2}{*}{$\begin{array}{l}\text { 基礎側面 } \\
\text { 埋戻し条件 }\end{array}$} & \multirow{2}{*}{$\begin{array}{l}\text { 基礁底面 } \\
\text { 接触条件 }\end{array}$} & \multicolumn{4}{|c|}{ 上部構遙階数条件 } \\
\hline & & & & & $\mathrm{OF}^{*}$ & $8 \mathrm{~F}$ & $11 \mathrm{~F}$ & $15 \mathrm{~F}$ \\
\hline \multirow{2}{*}{ 地盤のみ } & 第2種 & - & - & - & 0 & $=$ & - & - \\
\hline & 第3種 & $\bar{E}$ & - & - & 0 & $=$ & - & - \\
\hline \multirow{5}{*}{ 直接基礎 } & & $8 \% *$ & 有 & \multirow{7}{*}{ 接触 } & 0 & 0 & 0 & 0 \\
\hline & 第2種 & & 無 & & & & 0 & \\
\hline & & $16 \%$ & 有 & & & & 0 & \\
\hline & 䇫3種 & $8 \%$ & 直 & & & & 0 & \\
\hline & 牙ல性 & & 無 & & & & & \\
\hline \multirow{5}{*}{ 杭基礎 } & & \multirow{5}{*}{$8 \%$} & 有 & & & 0 & 0 & 0 \\
\hline & 第2種 & & 無 & & & & 0 & \\
\hline & & & 無 & 非接触 & 0 & & 0 & \\
\hline & 第3種. & & 有 & 接触 & 0 & O & 0 & 0 \\
\hline & & & 無 & 技嵒 & & & 0 & \\
\hline
\end{tabular}

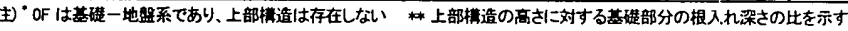

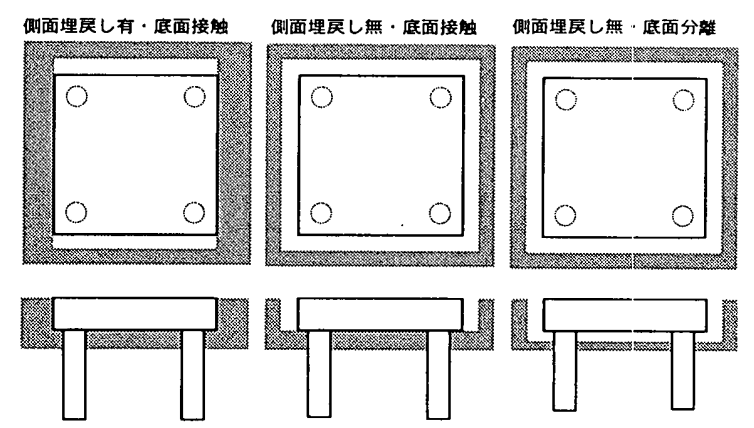

図 3 基礎根入れ部周辺の土圧作用の状態 
d) 基礎根入れ部周辺条件(3 種類): 基礎根入れ部亡 周辺地盤との接触条件を、図3のように設定した。 i)基礎根入れ部側面と底面が地盤と密着(側面埋 戻し有、底面接触)。ただし原型の 2 スパン分の 模型であるため、振動方向と平行する模型側面に は摩擦力が作用しないよう溝(隙間 $20 \mathrm{~mm}$ 程度)を 設け、地盤と接触していない。側面の埋め戻し部 分の地盤物性は表層地盤のそれとほぼ同一であ る。ii) 基礎根入れ部の底面のみが地盤と接触。 振動直交方向の根入れ側面に隙間( $40 \mathrm{~mm}$ 程度)を 設け、土圧は作用しない(側面埋戻し無、底面接
表 311 階建上部構造 模型の諸元

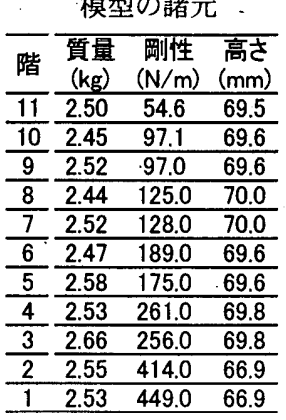

表 4 上部構造の基礎固定時の固有周期と減衰定数

\begin{tabular}{|c|c|c|c|c|c|c|}
\hline \multirow{3}{*}{ 建物 } & \multirow{3}{*}{ 次数 } & \multicolumn{4}{|c|}{ 荑験值 } & \multirow{3}{*}{$\frac{\text { 計算値 }}{\text { 振動数 }(\mathrm{Hz})}$} \\
\hline & & \multicolumn{2}{|c|}{ 自丒振動 } & \multicolumn{2}{|c|}{ スイーブ加振 } & \\
\hline & & 振動数 $(\mathrm{Hz})$ & 減衰定数 & 振動数 $(\mathrm{Hz})$ & 減衰定数 & \\
\hline \multirow{2}{*}{$8 \mathrm{~F}$} & 1 & 24.4 & 0.00190 & 24.4 & 0.00254 & \begin{tabular}{|l}
27.2 \\
\end{tabular} \\
\hline & 2 & 67.0 & -- & - & - & 66.9 \\
\hline \multirow{3}{*}{$11 \mathrm{~F}$} & 1 & 18.6 & 0.00182 & 18.5 & 0.00296 & 20.3 \\
\hline & 2 & 50.5 & $-\div$ & - & - & 53.6 \\
\hline & 3 & 84.5 & - & -- & -- & 8.1 .1 \\
\hline \multirow{5}{*}{$15 \mathrm{~F}$} & 1 & 11.2 & 0.00185 & 11.2 & 0.00285 & 13.1 \\
\hline & 2 & 32.2 & - & 32.2 & 0.00253 & 32.0 \\
\hline & 3 & 54.4 & - & -- & -- & 51.8 \\
\hline & 4 & 75.2 & - & - & $=$ & 71.1 \\
\hline & 5 & 93.6 & -- & -- & - & 87.7 \\
\hline \multicolumn{2}{|c|}{ 備考 } & $\begin{array}{l}\text { 自由搙勔波形 } \\
\text { のFFT処理 }\end{array}$ & 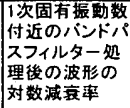 & 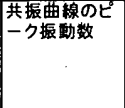 & 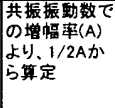 & 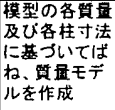 \\
\hline
\end{tabular}

触)。 iii)根入れ部側面、底面とも地盤と非接触(底面と地盤との隙 間 $10 \mathrm{~mm}$ 程度)。上部構造からの慣性力には杭のみで抵抗する。

\section{2 模型試験体の特徽と特性}

上部構造一杭基礎一地盤連成系模型試験体および加速度計の配置 と記号を図 4 に示す。

(1)上部構造模型とその特性

11 階上部構造模型における各階の質量、剛性等をまとめ、表 3 に 示す。図 5 に示すように、上部構造模型は鋼材を用いて作製され、 板バネの柱(幅 53〜 104mm: 厚さ 1.6〜3.2mm)と床位置でのおもり(厚 さ $12 \mathrm{~mm}$ で平面が $100 \mathrm{~mm}$ 角と $120 \mathrm{~mm}$ 角の鉄板を 1 枚ずつ)から構成 されている。

実験結果から得られた $8 、 11 、 15$ 階建上部構造模型の基礎固定時 の固有振動数と減衰定数の值を表 4 に示す。計算值は上部構造模型 の值(表 3)に基づいて固有值計算した結果である。加振条件における 減衰定数にはわずかに差が見られるものの、固有振動数はほぼ一定 の值である。上部構造模型の固有振動数の実測值と計算值を比較す ると、1 次モードでは計算值の方がわずかに高くなっている。 (2)杭基礎模型とその特性

図 6 に示す杭基礎模型(基礎根入れ部と 4 本の杭で構成されてい る)の基礎根入れ部はアクリルとアルミニウム製であり、基礎根入れ 部の剛性は非常に大きい。基礎根入れ部および杭模型の諸元を表 5 に示す。上部構造の階数に関係なく、基礎根入れ部および杭は同じ 寸法であるが、基礎根入れ部の質量は上部構造の階数に対応させ調 整した。杭の頭部は基礎根入れ部底面に接合されており、ほほ杭頭 回転拘束の条件が満たされている。杭模型は鋼板(幅 $38 \mathrm{~mm}$ 、厚さ $4.5 \mathrm{~mm}$ )の周辺にゴムを張り付けて円柱状（直径 $38 \mathrm{~mm}$ 、長さ $487 \mathrm{~mm}$ ) にし、断面形状と曲げ剛性を原型と相似にしている。杭の曲げ剛性、 減衰定数は、杭頭固定の片持ち梁の静的試験、自由振動試験から評 価し、曲げ剛性は $57.5 \mathrm{Nm}^{2}$ 、減衰定数は $5.5 \%$ である。杭先端は地表 面から $550 \mathrm{~mm}$ の位置にある。杭先端はせん断波速度の大きい地盤 に支持される条件が必要であるが、原型地盤のせん断波速度 $400 \mathrm{~m} / \mathrm{s}$ 以上に対応する地盤模型が作製できなかったこと、および杭先端を 振動台上に直接支持させると杭先端で鈶直変位が発生しないことを 考虑して、杭先端は第 2 種地盤と同様の物性を有 する層に支持されている (図 4.参照)。

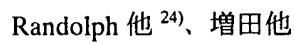
25)の方法により ${ }^{26) 、 3.1 ~}$ 節
表 5 基礎根入れ部・杭模型の諸元

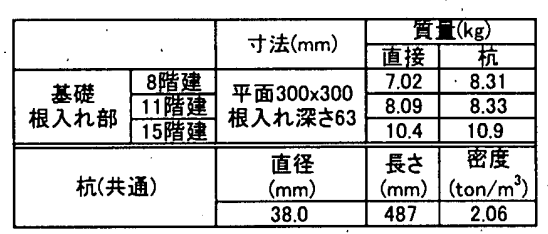
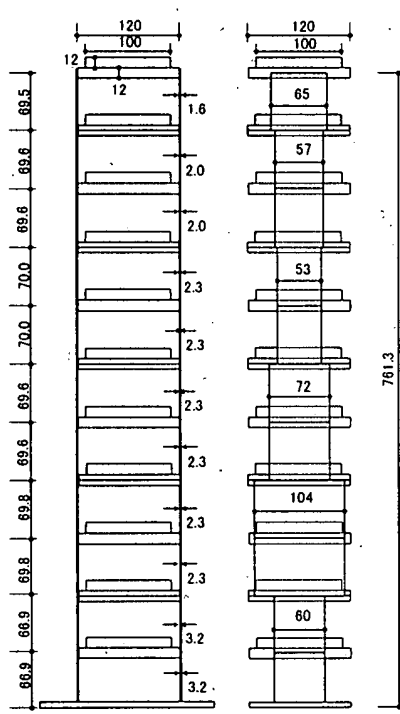

図 511 階建上部構造模型試験体 (単位 $\mathrm{mm}$ )

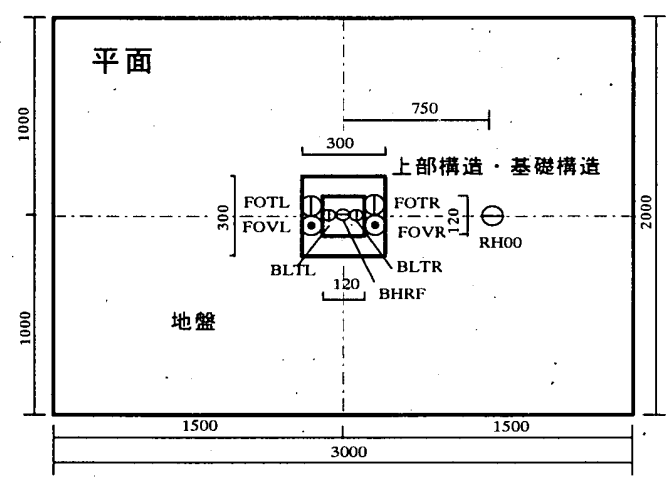

立面

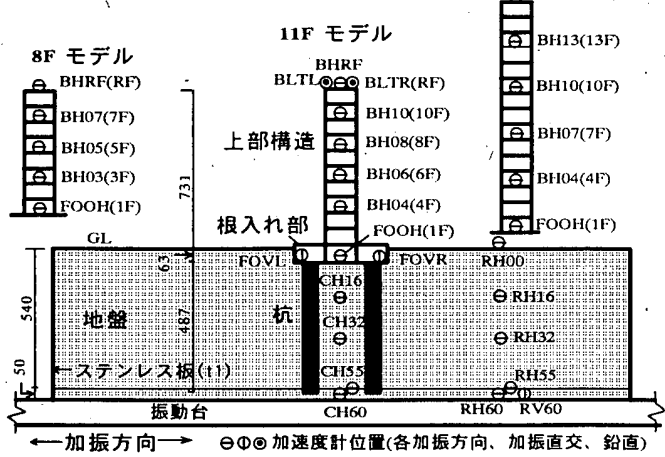

図 4 上部構造一杭基礎一地盤連成系模型試験体 および計測点位置(単位 $\mathrm{mm}$ )

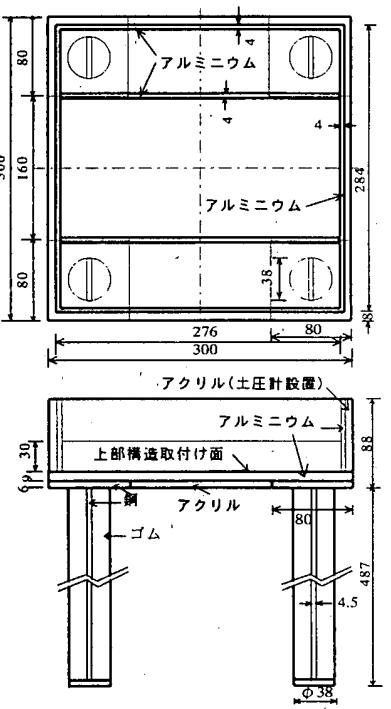

図 6 基礎根入れ部亡杭模型 (単位 $\mathrm{mm}$ ) 
の設定パラメータに示した原型地盤と模型地盤における杭頭剛性を 求め、その結果を比較すると表 6 となる。模型において鈶直剛性が やや小さくなるが、相似な関係はほぼ満足されている。

(3)地盤模型とその特性

地盤模型の平面寸法を加振方向 $3 \mathrm{~m}$ 、加振直交方向 $2 \mathrm{~m}$ とした(図 4 参照)。基礎根入れ部模型の平面寸法に対して、地盤の平面寸法は加 振方向で 10 倍、加振直交方向で 6.7 倍の大きさを有している。また 地盤模型の高さに対する長さの比が約 5 倍ある。地盤を大きくした 理由は、できる限り地盤のせん断変形を卓越させること、および地 盤模型の境界からの反射波の影響を小さくすることによっている。 さらに地盤が一様にせん断変形するために、水野・岡野他の実験で

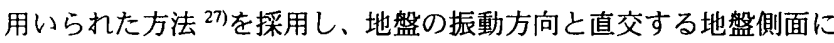
厚さ $1 \mathrm{~mm}$ のステンレス製の板を取り付け、地盤側面での鈶直変位 の発生を防止している。地盤模型の境界での反射波を発生させずに、 地盤の曲げ変形を防止する方法として、ウレタンフォーム ${ }^{23)}$ や水カ

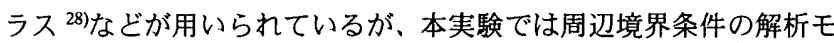
デル作成の容易さを考慮して、ステンレス板のみとした。

模型地盤の層構成と特性を、表 7 に示す。模型地盤はポリアクリ ルアマイドとベントナイトを用いて製作した ${ }^{2029)}$ 。第 2 種地盤は単 層構造であるのに対し、第 3 種地盤は、地盤層の下部に厚さ $50 \mathrm{~mm}$ のせん断波速度の大きい層(第 2 種地盤と同様の物性)を有する 2 層 構造である。地盤模型の特性は、S 波検層、スイープ加振およびテ ストピースの自由ねじり試験結果から求めた。スイープ加振による 第 2 種、第 3 種地盤の増幅特性を図 7 に示す。図中、CH00 は地表 面中央の加速度応答である。第 2 種、第 3 種地盤のせん断波速度の 平均值はそれぞれ約 $23.9 、 14.3 \mathrm{~m} / \mathrm{s}$ 、隇衰定数は約 $1.9 、 3.8 \%$ あるあ。 地盤の共振振動数は第 2 種地盤で 1 次 $10.1 \mathrm{~Hz} 、 2$ 次 $31.5 \mathrm{~Hz}$ 、第 3 種 地盤で 1 次 $6.41 \mathrm{~Hz} 、 2$ 次 $17.5 \mathrm{~Hz}$ となっている。

\section{3 計測項目}

計測項目は、地盤、基礎、建物内の加速度(図 4 参照)、基礎側面および底面での土圧、杭の曲 げひずみである。加速度計はひずみゲージ式

表 6 杭頭剛性の比較

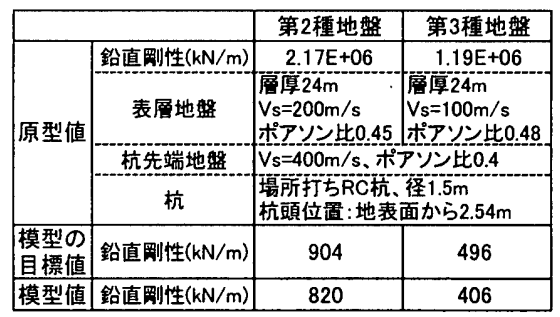

表 7 模型地盤の特性

\begin{tabular}{|c|c|c|}
\hline 地盤種別 & 第2種地盤(中程度) & 第3種地盤(軟弱) \\
\hline & GL & GL \\
\hline 地盤構成 & $0.59 \mathrm{~m} \quad V_{\mathrm{s}}$ & $0.54 \mathrm{~m} \quad \mathrm{v}_{\mathrm{s}_{1}}$ \\
\hline & & $0.05 \mathrm{~m} \quad \mathrm{Vs}_{2}$ \\
\hline $\begin{array}{c}\text { S波速度 } \\
(\mathrm{m} / \mathrm{s})\end{array}$ & $V s=23.9 \mathrm{~m} / \mathrm{s}$ & $\begin{array}{l}V s_{1}=14.3 \mathrm{~m} / \mathrm{s} \\
V s_{2}=23.9 \mathrm{~m} / \mathrm{s}\end{array}$ \\
\hline 卓越振動数 $(\mathrm{Hz})$ & $\begin{array}{l}\text { 1次 } 10.1 \mathrm{~Hz} \\
2 \text { 次 } 31.5 \mathrm{~Hz} \\
\text { (スイープ实段) } \\
\end{array}$ & $\begin{array}{l}\text { 1次 } 6.41 \mathrm{~Hz} \\
\text { 2次 } 17.5 \mathrm{~Hz} \\
\text { (同在) }\end{array}$ \\
\hline $\begin{array}{c}\text { 減衰定数 } \\
(\mathrm{X})\end{array}$ & 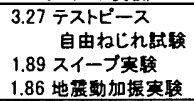 & 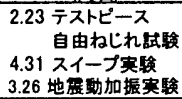 \\
\hline 密度 $\left(\mathrm{t} / \mathrm{m}^{3}\right)$ & 1.37 & 1.11 \\
\hline
\end{tabular}

$( \pm 2 \mathrm{~g})$ であり、上部構造(7 点)、基礎根入れ部(5 点)、地盤:内(10 点) に設置した。図 8a)に基礎根入れ部の側面での土圧計(容量 19.6〜 $147 \mathrm{kPa}$ )の配置を示す。地下階なし模型の場合、各側面に 3 点取り付 けている。図 8b)に、杭の曲げひずみ計測位置を示す。4 本ある杭の 内、 1 本は 6 点、他 3 本は杭頭の 2 点の曲げひずみを計測する。

3.4 加振内容とデータ処理方法

1)自由振動実験

上部構造の頂部に衝撃を加え、自由振動を発生させ、得られた自 由振動波形の複数の繰り返し(5 周期以上)から平均的な固有振動数 および対数減衰率を求めた。

2)スイープ加振実験

振動台は建築研究所の中型振動台 $(3 \times 4 \mathrm{~m}$ のテーブルを有する油 圧式水平一軸振動台、20ton 積載時で最大加速度 $1 \mathrm{~g}$ 、最大変位 $150 \mathrm{~mm}$ 、 最大速度 $1 \mathrm{~m} / \mathrm{s}$ の加振が可能)を用いた。また振動台における加速度 波形の制御するために、入力補償システムを使用した ${ }^{30)}$ 。振動台か らの入力として、スイープ波加振を行った。スイープ波加振は加振 時間の短縮が可能となり、短時間の信号から求められる伝達関数も 十分な精度が確保されることが報告されている ${ }^{31)}$ 。本奏験では目 標加速度振幅 $0.5 \mathrm{~m} / \mathrm{s}^{2}$ 、振動数漸増、振動数範囲 : $2-50 \mathrm{~Hz}$ 、スイープ 時間 : 約 70 秒の対数スイープ加振を採用した。

振動台の加速度振幅に対する各部の伝達関数の算定に法、高速つ ーリエ変換を用い、変換後のフーリエスペクトルに 3 回のハニング ウィンドウをかけた。

\section{4. 基礎入力動の特性と基礎部分で地震作用性状}

基礎入力動の評価には無質量基礎の応答結果が必要であるが、基 礎質量の影響は小さいことが報告されていることから ${ }^{32) 、 こ こ て ゙ は ~}$ 上部構造のない基礎一地盤系の応答結果を用いて基礎入力動の検討 を行った。スイープ

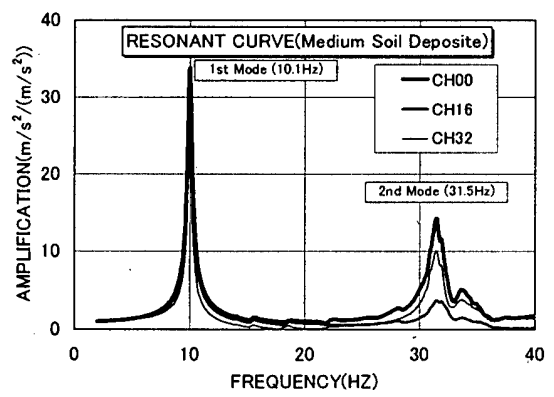

a)第 2 種地盤

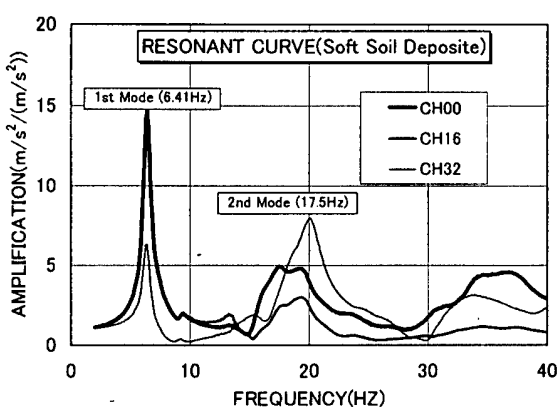

b)第 3 種地盤

図 7 第 2 種および 3 種地盤の増幅特性

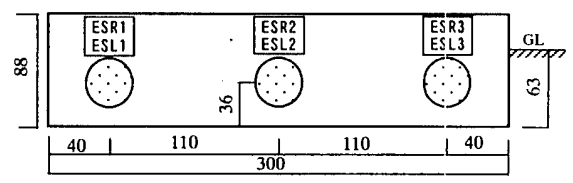

a)土圧計
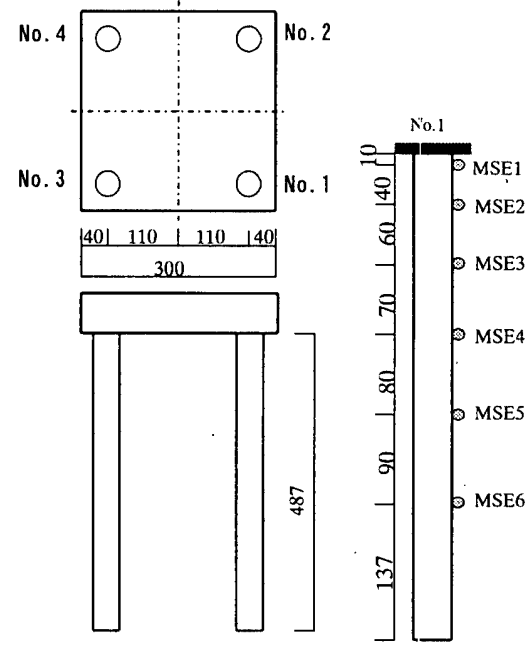

b)杭ひずみ計配置

図 8 基礎根入れ部の土圧計と杭の 曲げひずみ計測位置(単位 $\mathrm{mm}$ ) 


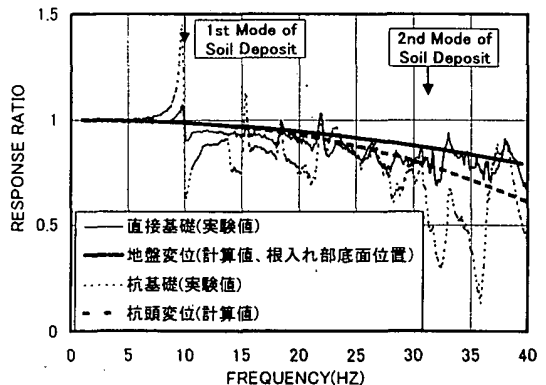

a)第 2 種地盤

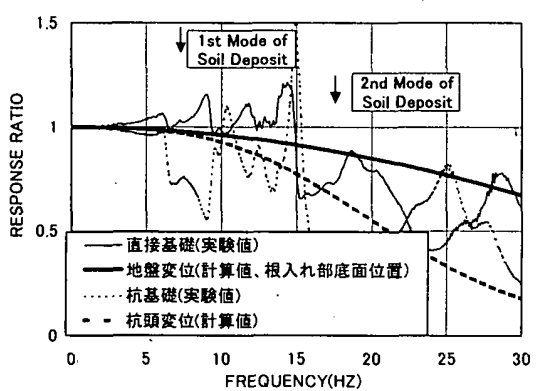

b) 第 3 種地盤

図 9 基礎構造による基礎水平入力動比の比較および簡易評価結果

を行った。スイープ加振における基礎入力 動の水平成分を地表面応答のそれで除した 值(以下、基礎水平入力動比と呼ぶ)の基礎構 造による比較(第 2 種および第 3 種地盤、土 圧作用)を図 9 に示す。眓からわかるように、 基礎水平入力動比はほほ 1 より小さく、振 動数とともに減少している。また基礎水平 入力動比は杭基礎で小さく、杭抵抗により 水平入力動が低隇されている。図中、基礎 底面位膡(杭基礎の場合は杭頭位置)におけ る地盤変位を地表面変位で無次元化した值 (図で地盤変位)を併せて示す。地盤变位は簡 易的に式(1)で与えた。

$$
u_{g}(z)=u_{g s} \cos \left(\frac{2 \pi}{\lambda} z\right)=u_{g s} \cos \left(\frac{\pi}{2} \frac{f}{f_{g}} \frac{z}{H}\right)
$$

ここに、 $u_{g} 、 u_{g s}$ はそれぞれ地盤変位、地表面変位、 $\lambda$ は波長、 $f^{\prime} f_{g}$ はそれぞれ波の振動数、地盤の 1 次卓越振動数、 $z 、 H$ はそれぞれ深 さ、地盤層厚である。

さらに杭変位は式(2)から求め、図 9 に杭頭での值を示した。

$$
E_{p} I_{p} \frac{d^{4} u_{p}}{d z^{4}}+\dot{B}_{p} k_{h}\left(u_{p}-u_{g}\right)=0
$$

ここに、 $u_{p}, E_{p} 、 I_{p} 、 B_{p}$ はそれぞれ杭の変位、弾性定数、断面 2 次モ 一メント、直径であり、 $k_{h}$ は水平地盤反力係数である。なお境界条 件は杭頭で回転拘束、杭先端でピンとした。水平地盤反力係数は式 (3)に示すFrancis の提案式から求めた ${ }^{33)}$ 。

$$
k_{h}=1.3 \frac{E_{s}}{1-v^{2}}\left(\frac{E_{s} B_{p}{ }^{4}}{E_{p} I_{p}}\right)^{1 / 12}
$$

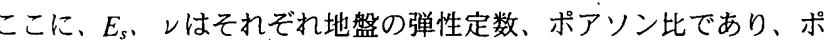
アソン比は 0.35 を用いた。式(3)より第 2 種、第 3 種地盤の水平地盤 反力係数は、それぞれ 66.3、17.3( $\left.\mathrm{MN} / \mathrm{m}^{3}\right)$ である。第 2 種地盤の場合、 地盤変位および杭頭変位の計算值は、実験結果の上限を包絡し、実 験結果との対応度は良い。一方、第 3 種地盤の場合、振動数の増加 とともに、杭の効果をやや過大評価する傾向を示している。

図 10 に、基礎根入れ部の側面土圧・底面摩擦作用の有無による基 礎水平入力動比(第 2 種地盤)を示す。基礎根入れ部周辺の土圧作用 の有無による差は少ないが、土圧・摩擦が作用しなくなると高振動 数域で值が上下に変動する割合が大きくなっている。

図 11 に、杭基礎の回転入力動の基礎根入れ部周辺地盤条件での比 較を示す。ここで基礎回転入力動比は角加速度に基礎半幅を乗じた

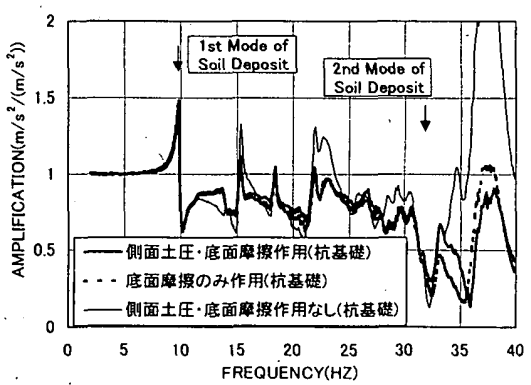

図 10 基礎水平入力動比の基礎周辺地盤条件 による比較(第 2 種地盤)

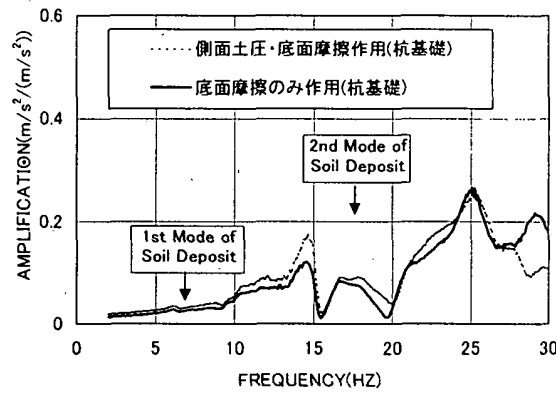

b) 第 3 種地盤

第 2 種地盤

周辺地盤条件による比較
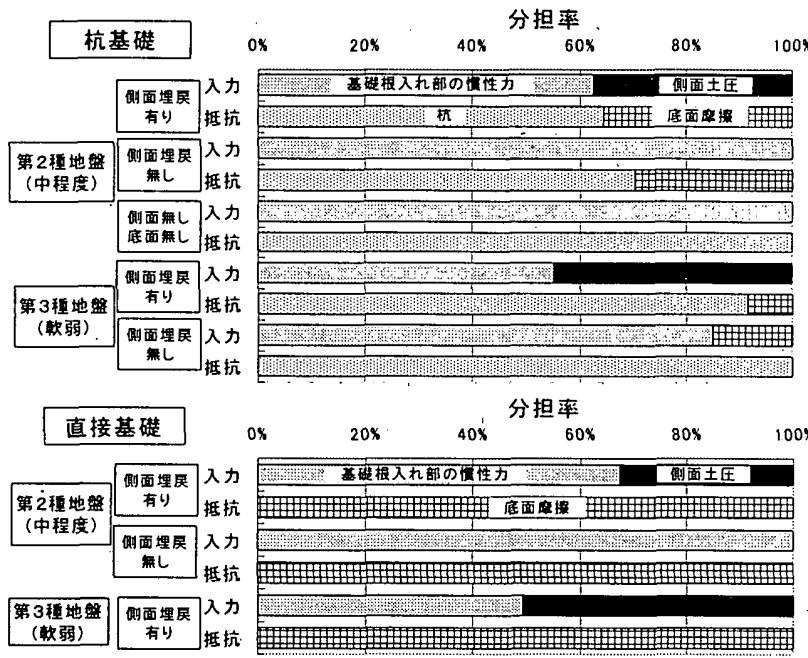

図 12 基礎根入れ部に作用する入力と抵抗要素とその割合

值を地表面応答で除した值とした。基礎回転入力動比も周辺土圧の 作用の有無による影響は小さい。地盤の 1 次卓越振動数近辺では基 礎回転入力動比は小さいが、地盤の 2 次卓越振動数近辺でその割合 は地表面応答の 2 割程度であり、11 階建物頂部の水平動に換算する と、地表面応答と同程度となっている。基礎回転入力動は無視でき る大きさではないが、地盤の 2 次卓越振動数付近での現象であるこ とを考えると、基礎回転動の建物応答への影響は小さい。

図 12 に、地盤の 1 次卓越振動数における基礎構造および周辺地盤 条件による基礎根入れ部に作用する入力と抵抗の関係を示す。基礎 根入れ部慣性力、側面土圧および杭頭水平力は、基礎根入㧈部慣性 力が最大值を示す時刻における值である。図 1 に示したように、地 盤振動に強制された結果、基礎が振動するため、基礎の側面土圧は 
基礎に対して入力として作用している。杭基礎の場合、杭は抵抗要 素となるが、基礎根入れ部底面の摩擦力は第 2 種地盤では抵抗、第 3 種地盤では入力として作用し地盤条件により差が生じる。地盤が 軟らかくなると、側面土圧と杭抵抗の割合がやや大きくなっている。

\section{5. 連成系における上部構造の振動特性と基砚部分での外力分担}

地盤との連成系における上部構造の振動特性は、上部構造の自由 振動実験結果から求めた。表 8 および表 9 に、それぞれ連成系にお ける上部構造の共振振動数と対数減衰率の一覧および建物頂部に占 めるスウェイ、ロッキング、建物変形の相対值の一覧を示す。

\section{(1)上部構造の共振振動数}

基礎固定時の共振振動数 $\left(\mathrm{f}_{\mathrm{BF}}\right)$ に対する、杭基礎(側面埋戻し有)にお ける連成系の共振振動数 $\left(\mathrm{fb}^{*}\right)$ の比は、第 2 種、第 3 種地盤でそれぞ れ 59 68\%、43〜 48\%と低くなる。周辺土圧が作用しない場合(側面 埋戻し無)や直接基礎の場合にはさらに低下する。

(2)連成系の振動モード

図 13 に、自由振動における建物頂部の加速度応答に占 める杭基礎のスウェイ、ロッキング、上部構造の応答の割 合を、建物階数別、基礎根入れ部周辺地盤条件別に示す。 共振振動数が低下する要因として、基礎のロッキング成分 がかなりの割合を占めていることが挙げられる。基礎根入 れ部周辺に土圧が作用しなくなると、基礎のロッキング成 分はやや增加するが、スウェイ成分の增加が顕著である。 (3) 上部構造の減衰定数

基礎固定時における上部構造の対数减衰率は、 $0.2 \%$ 程度 であるのに対し、連成系では第 2 種地盤で 2 3\%程度、第 3 種地盤で 4 5\%程度となる。表 7 より、地盤の減衰定数 は、第 2 種、第 3 種地盤でそれぞれ約 $1.9 \% 、 3.8 \%$ あり、 上部構造の減衰定数は、地盤の材料減衰定数之同等かまた はそれより大きい值になっている。この結果は、上部構造 の減衰には地盤の材料減衰に加えて、地下冕散による振動 エネルギーの消散が関係していることを示すものである。 表 10 に、上部構造のベースシア(基礎根入れ部分の慣性
力を含む)に対する基礎根入れ各部分での反力としての負担割合を 示す。図 1 に示すように、抵抗要素として、基礎根入れ部の側面土 圧・底面摩擦および杭の水平抵抗力がある。側面土圧と杭の水平抵 抗による負担力は計測值に基づいて算定した。底面摩擦負担分はべ ースシアから側面土圧と杭の水平抵抗力を引いた值となる。ここで は基礎根入れ部の側面土圧の負担力は、側面に取り付けた土圧計測 值の平均值に面積を乗じて求めた。また前後の 2 面で計測された側 面土圧の作用方向が逆位相となるため、両面の土圧が反カとして有 効であるとした。杭については、均質地盤に設置された半無限長の 杭を仮定(Chang の式を適用)し、実験で得られた杭曲げモーメント 分布から最小 2 乗法により、杭の水平抵抗力とロッキング角を求め た。得られたロッキング角は実験における基礎のロッキング角とほ ほ対応していた。基礎根入れ部の側面土圧による分担率が非常に大 きく、その場合には杭の水平抵抗力の分担率は小さくなる。

表 8 連成系における上部構造の共振振動数と対数減衰率

\begin{tabular}{|c|c|c|c|c|c|c|c|c|c|c|c|c|c|}
\hline \multirow{3}{*}{ 地盤条件 } & \multirow{3}{*}{ 基碅 } & \multirow{3}{*}{\begin{tabular}{|l} 
根入れ \\
深さ( $)$
\end{tabular}} & \multirow{3}{*}{\begin{tabular}{|l|} 
根入れ \\
䁌面 \\
\end{tabular}} & \multirow{3}{*}{$\begin{array}{l}\text { 染件 } \\
\text { 底面 }\end{array}$} & \multirow{2}{*}{\multicolumn{3}{|c|}{ 88箸建 }} & \multirow{2}{*}{\multicolumn{3}{|c|}{ 建物条件 }} & \multirow{2}{*}{\multicolumn{3}{|c|}{ 15贊建 }} \\
\hline & & & & & & & & & & & & & \\
\hline & & & & & $\mathrm{fb}^{*}(\mathrm{~Hz}$ & $\mathrm{bb}^{*} / \mathrm{f}_{\mathrm{BE}}$ & $h(\%)$ & $\mathrm{fb}^{*}(\mathrm{~Hz}$ & $\mathrm{fb}^{*} / \mathrm{f}_{\mathrm{BE}}$ & $h(*)$ & $\mathrm{fb}^{*}(\mathrm{~Hz}$ & $\overline{\mathrm{fb}^{*} / \mathrm{f}_{\mathrm{BB}}}$ & $h(x)$ \\
\hline なし & 基硞 & & & & 24.4 & 1.000 & 0.191 & 18.6 & 1.000 & 0.184 & 11.2 & 1.000 & 0.181 \\
\hline \multirow{4}{*}{ 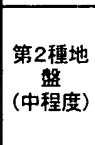 } & & 8 & & \multirow{3}{*}{ 密着 } & 12.2 & 0.500 & 2.12 & 7.94 & 0.428 & 2.90 & 5.25 & 0.467 & 2.53 \\
\hline & 䣫接 & & 無 & & & & & 5.86 & 0.316 & 3.78 & & & $\angle$ \\
\hline & \multirow[b]{2}{*}{ 杭 } & \multirow{3}{*}{8} & \multirow{3}{*}{ 無 } & & 16.5 & 0.675 & 1.71 & $\frac{9.28}{10.9}$ & 0.585 & $\frac{2.26}{1.85}$ & 696 & 0620 & 198 \\
\hline & & & & & & & & 9.16 & 0.494 & 2.49 & & & \\
\hline \multirow{3}{*}{$\begin{array}{c}\text { 第3種地 } \\
\text { 繋 } \\
\text { (軟弱) }\end{array}$} & & & & & & & & & 0.474 & 2.89 & & & \\
\hline & 直接 & \multirow[t]{2}{*}{8} & 有 & \multirow{2}{*}{ 密着 } & 117 & 0480 & 473 & 4.76 & $\frac{0.257}{0.48}$ & $\frac{2.64}{378}$ & 525 & $\overbrace{0467}$ & 439 \\
\hline & 杭 & & 無 & & & & & 7.32 & 0.395 & 4.91 & & & \\
\hline
\end{tabular}

表 9 連成系における上部構造のスウェイ、ロッキング、建物愁形率

\begin{tabular}{|c|c|c|c|c|c|c|c|c|c|c|c|c|c|}
\hline \multirow{3}{*}{ 地盤条件 } & \multirow{3}{*}{ 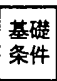 } & \multirow{3}{*}{\begin{tabular}{|l} 
根入れ \\
深さ(\%)
\end{tabular}} & \multicolumn{2}{|c|}{ 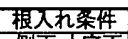 } & \multicolumn{9}{|c|}{ 建物条件 } \\
\hline & & & \begin{tabular}{|l|l|} 
側面 \\
\end{tabular} & 底面 & \multicolumn{3}{|c|}{ 8陼建 } & \multicolumn{3}{|c|}{ 11階建 } & \multicolumn{3}{|c|}{ 15管建 } \\
\hline & & & 埋屈 & & $x=x$ & 口ッキン & 进物变开 & ZZII & 口ッキン & 可建物变 & $x=x$ & בッキン & 䢖物变开 \\
\hline な & $\begin{array}{l}\text { 基整 } \\
\text { 定 }\end{array}$ & & & & 0.001 & 0.008 & 0.991 & 0.001 & 0.013 & 0.986 & 0.001 & 0.009 & 0.990 \\
\hline \multirow{5}{*}{$\begin{array}{l}\text { 第2種地 } \\
\text { (中程 } \\
\text { (中度) }\end{array}$} & \multirow{3}{*}{ 直接 } & 8 & & & 0.066 & 0.592 & 0.342 & 0.044 & 0.749 & 0.207 & 0.035 & 0.715 & 0.250 \\
\hline & & & 無 & & & & & 0.056 & 0.815 & 0.129 & & & \\
\hline & & 16 & 直 & & & 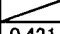 & 2 & 0.078 & 0.640 & 0.282 & 50 & 5 & 107 \\
\hline & \multirow{2}{*}{ 标 } & \multirow{2}{*}{8} & \multirow[t]{2}{*}{ 且 } & & 0.010 & & & 0.051 & 0.474 & 0.476 & 0.056 & 0.456 & 0.481 \\
\hline & & & & 分離 & & & & 0.155 & 0.549 & 0.296 & & & \\
\hline \multirow{3}{*}{ 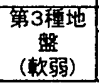 } & 面接 & & 有 & \multirow{3}{*}{ 密着 } & & & & 0.054 & 0.821 & 0.125 & & & 1 \\
\hline & 杭 & & & & 0.155 & 0.547 & 0.298 & 0.153 & 0.605 & 0.242 & 0.110 & 0.609 & 0.281 \\
\hline & & & & & & & & 0.154 & 0.567 & 0.279 & & & \\
\hline
\end{tabular}

表 10 ベースシアに対する基礎での荷重分担率

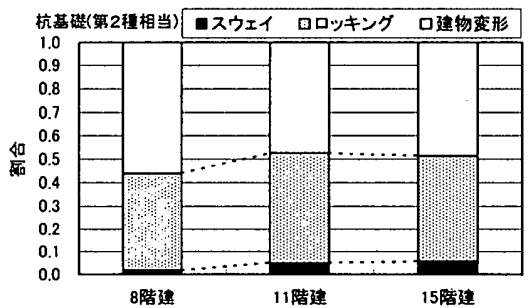

a)上部構造階数別

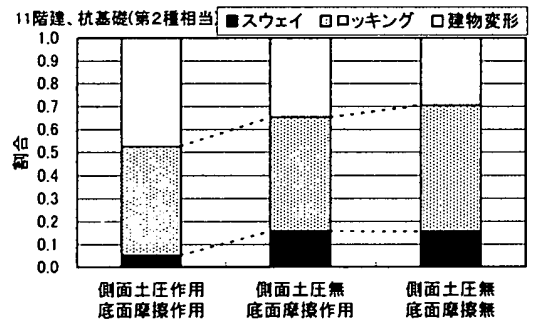

b)基礎根入れ部周辺地盤条件別

図 13 スウェイ、ロッキング、建物変形率
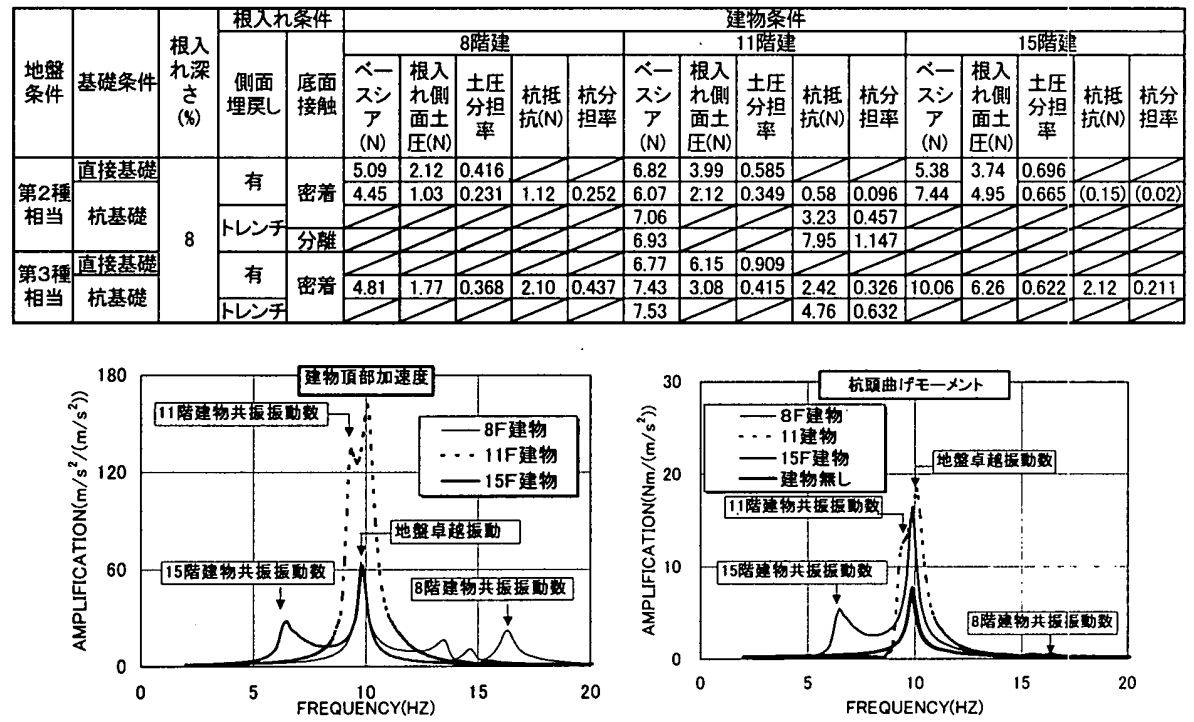

図 14 上部構造一杭基礎一地盤系の増幅特性(上部構造別) 


\section{6．建物一地盤全体系の増幅特性と杭曲げモーメントへの影䜾}

(1)上部構造一杭基礎一地盤系の增幅特性

図 14 に、地盤底面(振動台入力)の加速度振幅に対する建物頂部の 加速度および杭頭曲げモーメントの各增幅特性の上部構造別の比較 を示す。連成系における上部構造の共振振動数および地盤の卓越振 動数での増幅率は大きい。特に 11 階建物の場合、上部構造と地盤と の共振振動数が非常に近接したため、加速度応答および杭曲げモー メント応答は非常に大きい。地盤の卓越振動数付近での杭頭曲げモ 一メントは、上部構造慣性力とともに、地盤変位の影響(図 14 で、 建物無しが地盤振動のみの影響を示す)も受けている。

図 15 に、11 階建物における、基礎根入れ部周辺地盤条件による 杭頭曲げモーメントの増幅特性を示す。土圧が作用しない場合には、 連成系における上部構造の共振振動数が低下し、地盤卓越振動数と 離れるため、増幅率は小さくなる。図 16 に、基礎根入れ部周辺地盤 条件による、連成系における上部構造の共振振動数での上部構造一 杭基礎系の加速度分布および杭の曲げモーメント分布(一部基礎根 入れ部土圧を含む)を示す。基礎根入れ部周辺の条件が異なると、杭 の曲げモーメント分布に大きな差が生じている。

(2)上部構造慣性力と地盤変位の杭曲げモーメント分布への影響

ここで上部構造一杭基礎一地盤系における杭の曲げモーメントの 簡易評価を行う。杭の曲げモーメントの算定にあたうては、均質地 盤に設置された半無限長の杭を仮定(Chang の式を適用)する。この とき杭応力に影響する要因として、上部構造のベースシア(基礎根入 れ部の慣性力も含む)、基礎根入れ部のロッキング角と地盤変位を考 える。杭頭に作用する水平力は、表 10 のベースシア分担率に基づき、 杭 1 本の値として求め、基礎のロッキング角は実験值を用いた。地 盤変位は式(1)を用い、地表面変位は振動数と地表面の加速度振幅よ り求め、式(2)より杭変位・応力を求めた。

図 17 に、基礎根入れ 部周辺地盤条件による 杭曲げモーメント分布 の計算值と実験值の比 較を示す。基礎根入れ部 土圧・底面摩擦とも作用 しない場合、杭曲げモー メントは杭頭水平力に よるモーメントが支配 的である。また基礎根入 れ部のロッキングによ

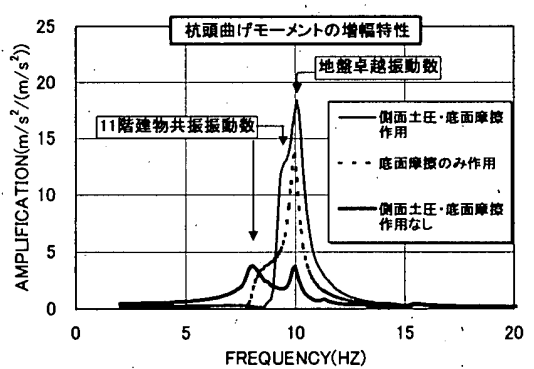

図 15 上部構造一杭基礎一地盤系の杭頭曲げ モーメント增幅特性(基礎根入れ部周辺地盤別)
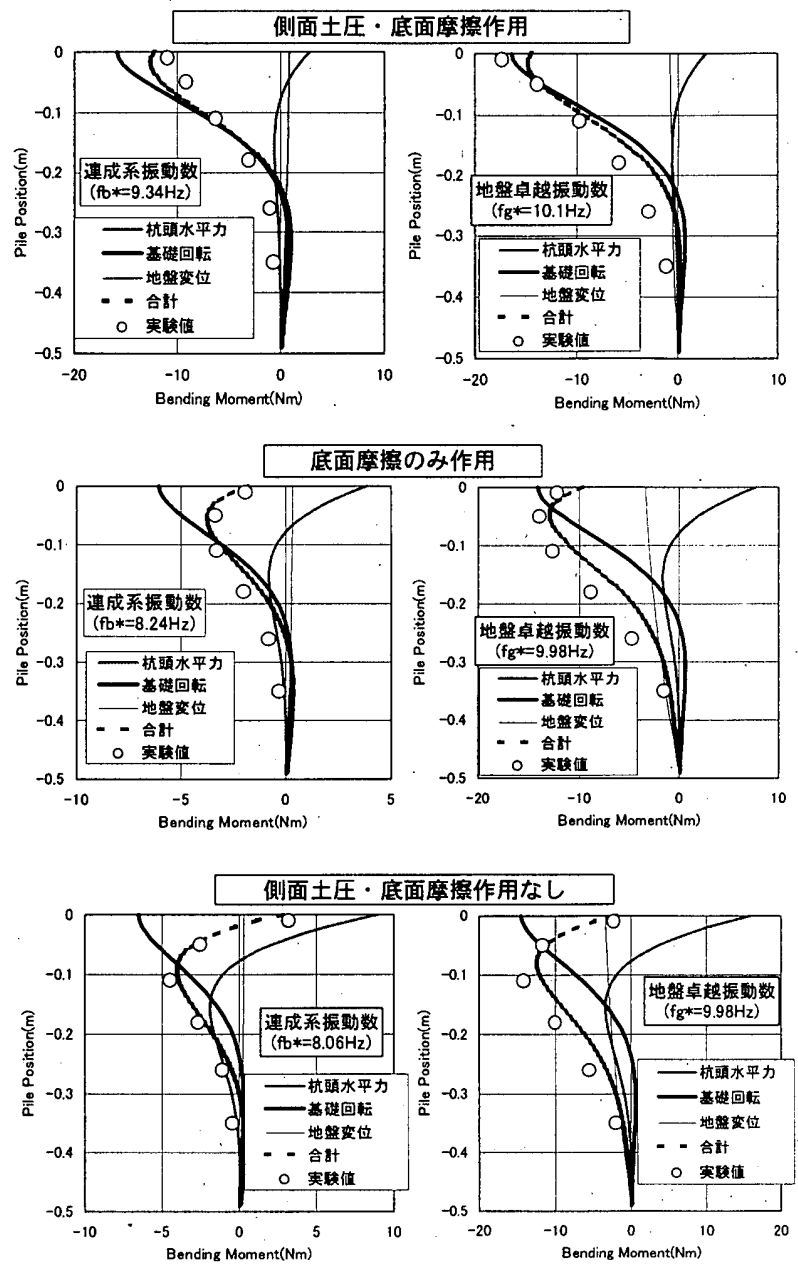

a)第 2 種地盤

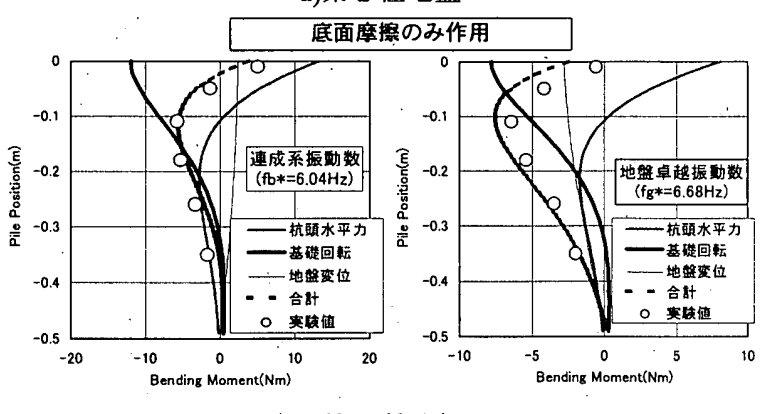

b)第 3 種地盤

図 17 上部構造慣性力之地盤変位による杭曲げモーメント分布の 計算值と実験值の比較(基礎根入れ周辺地盤別、11 階建物)
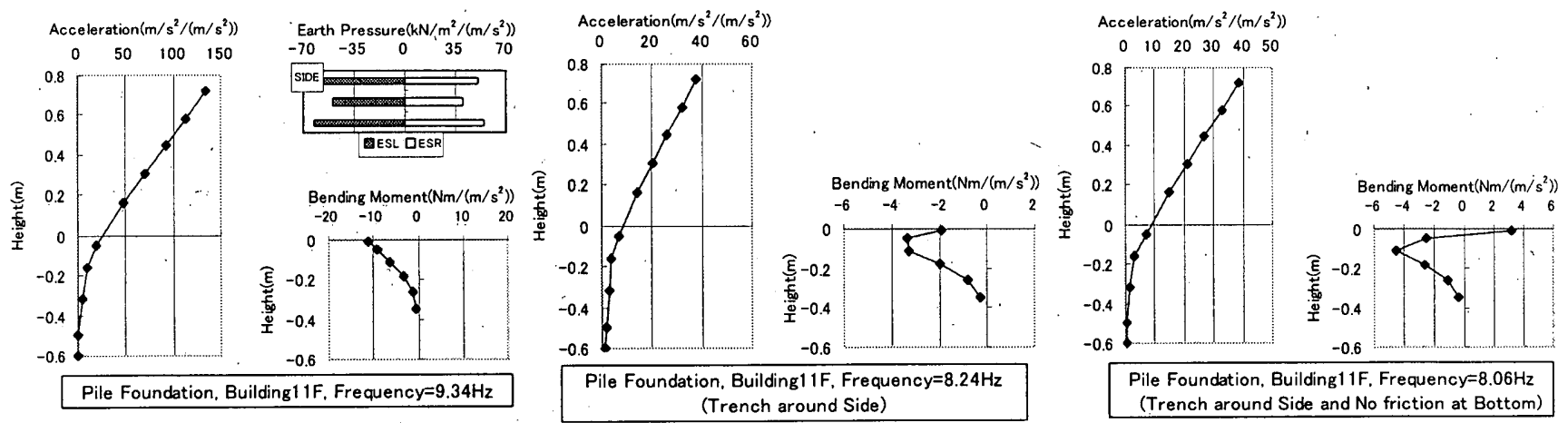

図 16 上部構造一杭基礎一地盤系の連成系共振振動数増幅分布(基礎根入れ部周辺地盤別、11階建物) 
り、水平力と同等の曲げモーメントが杭頭に生じるが、水平力によ る曲げモーメントとは向きが反対となるため、両者の影響を合わせ ると杭頭曲げモーメントは小さくなり、杭頭ピン条件での分布形之 調和的となる。次に底面摩擦のみが作用する場合、杭頭曲げモ一メ ントへの基礎根入れ部のロッキングの影響は大きく、さらに側面土 圧と底面摩擦が作用すると、上部構造のベースシアの一部しか杭に 作用しないため、基礎根入れ部のロッキングによる影響が顕著とな る。一方、地盤卓越振動数では、地盤変位により生じる杭曲げモ一 メントの割合も大きく、地盤変位の影響を考慮する必要がある。

\section{7. まとめ}

壁式ラーメン構造を有する建物の梁間方向を対象とした上部構造 一杭基礎一地盤連成系模型による振動台実験を行い、地震時におけ る杭基礎への入力作用および抵抗機構に関する基本的特性の検討を 行った。主な検討結果を要約すると以下のようになる。 1)地表面の応答に対する基礎入力動の比は振動数とともに低下し、 直接基礎に比べて杭基礎の方が低下の割合が大きい。これは地盤変 位に対する杭の抵抗によると考えられる。地下階がない場合、地盤 の 2 次卓越振動数周辺での回転入力動は、地表面応答の 2 割程度で あり、11 階建物頂部の水平動に換算すると、地表面応答と同程度と なっている。地盤の 2 次卓越振動数付近での現象であることを考え ると、基礎回転動の建物応答への影響は小さいと考えられる。

2)上部構造の剛性が大きい建物では、基礎のロッキング変位の影響 が大きく、根入れ部側面が埋め戻された杭基礎の場合、連成系にお ける上部構造の共振振動数は基礎固定時のそれに対して、第 2 種、 第 3 種地盤でそれぞれ 59〜 68\%、43〜 48\%である。 3)基礎固定時の上部構造の減衰定数(約 $0.2 \%$ )に比べて、連成系の減 衰定数は、第 2 種、第 3 種地盤でそれぞれ 2 3\% 程度、4 5\%程度 と增加する。この值は地盤の材料減衰よりも大きく、地下逸散によ る振動エネルギーの消散効果が含まれていると考えられる。 4)杭基礎は上部構造のベースシアや転倒モーメントに加えて地盤変 位の影響を受ける。基礎のロッキングによる杭頭の曲げモーメント の大きさは、上部構造のベースシアのすべてが杭に作用するとした 場合の水平力による值とほぼ同程度となる。このとき曲げモーメン トの向きは逆となる。ベースシアの一部が根入れ部の側面土圧や底 面摩擦で負担されるにつれて、杭頭の水平力が低減するため、基礎 のロッキングの影響が顕著となる。また地盤卓越振動数では、地盤 変位により生じる杭曲げモーメントの割合も大きく、その影響を考 慮する必要がある。

\section{謝辞}

本研究恃、HFW 構造設計・施工計画指針作成を目的とした「HFW 推進委 員会」(日本建築センター)の研究活動の一瑟として設置された HFW 構造性能 分科会、HFW 指針分科会のもと、「入力地震動評価に関する実驗的研究」に 関する作業部会(主査：松島豊筑波大名举教授)で実施されたものである。また 実験の遂行に当たり、水野二十一建築研究所研究尃門役より多くの助言を頂 いた。ここに関係各位に感謝いたします。

\section{参考文献}

1) 井口道雄 : 動的相互作用研究の近年の動向と今後の課題-1980 年以降の日 本の動向を中心として、第 6 回構造物と地盤の動的相互作用シンポジウ 厶資料集、日本建策学会、pp.5-28、2001.3

2）太田外気晴、丹羽正徳、上野蒸 : 軟弱地盤上杭基礎建物の地震応答性状、 第 5 回日本地震工学シンボジウム講演集、pp.540-546、1978.11

3) Sugimura, Y. : Earthquake Observation and Dynamic Analysis of Pile Supported Buildings, Procs. of the $4^{\text {th }}$ Japan Earthquake Engineering Symposium, pp.463-470, 1975.11

4) 日本建築学会 : 入門・建物と地盤との動的相互作用、吕資料編、III-2 模 型实験と観測の方法、pp.318-323、1996.4

5）矢島淳二：杭基礎の耐震設計に関する諸問題、第 2 編第 1 章 1.1 杭基礎の 地震観測の見状、建築基礎の設計施工に関する研究資料 6、日本建築学会、 pp.111-116、2000.4

6) 境一男: 釧路地方気象台の地震記録に見られる地盤と建物の相互作用効果 およびそのシミュレーション、日本建築学会構造系論文集、第 470 号、 pp.75-84、1995.4

7) 安井譲、井口道雄、赤木久真、林康裕、中村充：1995 年兵庫県南部地竺 における基礎有効入力動に関する考察、日本建築学会構造系訜文集、第 512 号、pp.111-118、1998.10

8）林康裕、藤森健史、安井初、井口道雄：1995 年兵庫県南部地震における 相互作用効果と建物応答、日本建筑学会構造系論文集、第 520 号, pp.45-51、 1999.6

9）福和伸夫：耐震設計における動的相互作用に関わる課題、第 6 回構造物と 地盤の動的相互作用シンポジウム資料集、日本建築学会、pp.135-150、 2001.3

10) 福和伸夫、飛田潤：建物一地盤の動的相互作用から見た強震観測、第 2 回强震データの利用に関するシンポジウム資料集、日本建築学会、 、pp.57-68、 2000.12

11）運輸省鉄道局監修、鉄道総合技術研究所編：鉄道構造物等設計標準・同解 説-耐震設計-、丸善、pp.107-111、1999.10

12）宮本裕司、酒向裕司、喜多村英司、三浦賢治：非線形、液状化地盤におけ る杭基礎の地震応答性状に関する研究、日本建策学会構造系諭文集、第 471 号、pp.87-95、2001.5

13）許斐信三、松尾雅夫、杉村義広 : 杭基礎の耐震設部に関する諸問題、第 2 編第 2 章応答変位法、建築基礎の設計施工に関する研究資料 6 、日本建築 学会、pp.135-150、2000.4

14）小林勝已: 基礎の設計法とクライテリア、第 6 回構造物と地盤の動的相互 作用シンポジウム資料集、日本建築学会、pp.99-114、2001.3

15）藤原攵 : 杭基整の耐震設計に関する諸問題、第 1 編第 2 章 2.2 地下室は耐 震性能上効果があるか、建築基礎の設計施工に関する研究資料 万、日本建 築学会、pp.19-28、2000.4

16) 北川良和、松島豊他: 地盤・建物連成系におけるせん断力係数分有一高首 壁式ラーメン構造に関する研究一(その 1) (その 5)、日本建築学会大会学 術講演梗概集、構造 B、pp.819-826、1988.10

17）飯場正紀: 杭体の応力に及ぼす地盤振動の影響(その 1)(その 2)、日本建築 学会東海支部研究報告集、pp.101-108、1983.2

18）小林勝已、森伸一郎: 基礎構造の酎震設計と相互作用を考慮した挑震荷重、 第 5 回構造物之地盤の動的相互作用シンポジウム資料集、日本建築学会、 pp.107-120、1998.5

19）杉村義弘、徐挺：简単なモデル解析による建物と地盤の動的相互作用、建 築技術、pp.52-55、pp.83-92、2001.6

20）水野二十一: 建物一杭基䃈一地盤系模型振動実䮦、土と基礎、Vol.28、No.5、 pp.47-54, 1980.5

21) 江守一郎、D.J.シューリング : 模型実験の理論と応用、技報堂出版、1981

22）小関慧幸、水野二十一、三浦㹂治他：杭支持建物における根入扎部・杭の 地震時水平力分担率模型実験(その 1)(その 2)、日本建䓩学会大会学術講演 梗概集、pp.1727-1730、1979.9

23）飯場正紀、水野二十一、北川良和他：模型試験体に上る動的相互.作用効果 の関する研究(その 1) （その 4)、日本建䓩学会大会学術講演梗概集、 pp.645-648、1981.10、pp.673-676、1982.10

24) Randolph, M. F. and C. P. Wroth : Analysis of Deformation of Vertically Loaded Piles, J. of Geotechnical Engineering Division, ASCE, Vol.104,No.GT12, pp. 1465-1488, 1978.12

25) 增田 彰、土方勝一郎他: 群杭の動的インピーダンス簡便評価法(その 1 ) 日本建築学会大会学術講演梗概集、構造 I、pp.339-340、1993.9

26）国土交通省建築研究所編著: 改正建築基淮法の模造関係規定の技術的背景、 ぎょうせい、pp.89-99、2001.3

27) 水野二十一、岡野創他 : 動的相互作用の模型振動台実験における地盤側面 境界処理(その 1 せん断境界処理装置の提案)、日本建筑学会大会学術㹃演 梗概集、構造 B、pp.189-190、1985

28）三浦賢治、伊藤幸爾郎、北川良和他：地霞時の基碟根入れ部土圧と杭応力

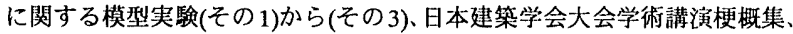
pp.619-624、1980.9

29）水野二十一、森信夫、小関孁幸: 模型地盤としてのポリアクリルアマイド の材料的性質(その 1 )、第 14 回土質(垷地盤)工学研究発表会論文集、 pp.109-112、1979.6

30）鹿嶋俊英、北川良和、田中洪、水野二十一：電算機一振動台オンラインシ ステムによる動的加力実蹹に関する研究、第 4 回電子計算機利用シンポジ ウ厶、日本建筑学会、1982

31）内藤幸雄、石橋敏久：新しい加振法による振動台実敇の改善、品質管理、 Vol.34、11 月臨時增刊号、日科技連出版社、pp.193-198、1983.11

32) 松島豊、水野二十一，風野創他 : 有效入力に着目した埋込み構造物の模开 振動実験とその解析、日本建築学会大会学術講演梗概集、構造 B、 pp.517-526、1986.8

33）横山幸满：くい構造物の計算法と計算例、山海堂、pp.77-78、1977.11 